\author{
Sustinere \\ Journal of Environment and Sustainability \\ Volume 4 Number 3 (2020) 144-154 \\ Print ISSN: 2549-1245 Online ISSN: 2549-1253 \\ Website: https://sustinerejes.com E-mail: sustinere.jes@iain-surakarta.ac.id
}

\title{
RESEARCH PAPER \\ Determination of Sentinel-2 spectral reflectance to detect oil spill on the sea surface
}

\author{
Pingkan Mayestika Afgatiani", Fanny Aditya Putri, Argo Galih Suhadha, \\ Andi Ibrahim \\ Remote Sensing Application Center, LAPAN, Indonesia \\ Article history: \\ Received 29 June 2020 | Accepted 28 September 2020 | Available online 31 December 2020
}

\begin{abstract}
Oil spill is one of the most common marine environmental problems. Oil spills can be caused by leakage at oil refineries at sea or disposal of vessel waste. This event has an impact on various sectors, such as fisheries, tourism, and marine ecosystems. This study aims to determine the spectral reflectance of Sentinel-2 response to detecting oil spill on the sea. Oil identification in the sea can be made visually by looking at colored patterns at sea level. Sentinel-2 image reflectance was obtained by processing the image using the Google Earth Engine platform. The results were clipped according to the area of interest and divided to get a value between 0 and 1 . Bands combination is possible to identify the oil spill visually. The silvery pattern saw in the red-green-blue combination, but it is arduous to estimate its distribution because of the silvery pattern seen for thick oil. The combination of SWIR-NIRred bands proved effective in showing the distribution of oil with a deep black pattern. Spectral measurements in the field were undertaken by taking samples in the areas of oil spills and clean water bodies. The oil layer had a lower reflectance than the clean water body. The blue band gave a high response, but the red band gave less response. In the NIR and SWIR bands, the reflectance of oil was lower than the water body. In conclusion, the SWIR - NIR RED band combination is better used to determine oil spills due to it shows the characteristics of oil generally, either thin or thick oil.
\end{abstract}

Keywords: Sentinel-2B; oil pollution; bands combination; oil pattern; oil reflectance

\section{Introduction}

Oil spill is one of the main problems in the marine environment, and the occurrence has been increasing recently. Oil spill pollution on the sea triggers issues against coastal ecosystems and directly impacts sea creatures. Elum et al. (2016) reveal that oil exploitation and its waste on the Niger Delta have increased environmental degradation and resulted in dead fish and crops, which threaten food security as well as the loss of farmlands and fishing activities in viable rivers. It also has a significant impact on socio-economic. The crude oil spill on the northern coast of Karawang, at least, resulted in losses of up to 700 million Rupiah in salt farmers and 232.000 mangroves along the coast of exposed to oil (Iqbal, 2019; Yolanda, 2019).

${ }^{*}$ Corresponding author. E-mail: pingkan.mayestika@lapan.go.id DOI: https://doi.org/10.22515/sustinere.jes.v4i3.115 
One of the causes of oil spills is the leakage in a marine oil refinery or vessel operational waste disposal. There have been several cases of oil spills in Indonesia and international waters such as oil spills in the waters of Balikpapan Bay in 2018 and Cilacap in 2015, the Montara platform on the Australian continental shelf in 2009, and Niger Delta, which has experienced more than 9000 incidences in the last ten years (Albert, Amaratunga, \& Haigh, 2018; Lamrotua Sihombing, Nurweda Putra, \& Arya Sasmita, 2018; Setiani \& Ramdani, 2019; Spies, Mukhtasor, \& Burns, 2017). The oil leakage at the well of YYA-1 is one of the attracted events of an oil spill in 2019. YYA-1 is one of three rigs in the YY Project by Pertamina Hulu Energi - Offshore North West Java (PHE ONWJ) located in Karawang.

To minimize the damage of the oil spill, there are three primary activities should be done according to (Ozigis et al., 2020). First, monitoring and detecting the oil spill's location to set the affected area of oil pollution. Second, facilitate repair and recovery of the oil spill. The last, monitor the impact of oil pollution on vegetation. Because oil that spilled into the sea will rapidly undergo the process of dispersion, evaporation, emulsification, dissolution, sedimentation, and oxidation (Sulistyono, 2013), it is necessary for faster technology to perform detection.

Remote sensing technology has the ability to perform oil spill detection quickly, effectively, and in vast areas. Remote sensing has several sensors that can be used to detect oil spills, including synthetic aperture radar (SAR) (Fan et al., 2010; Sulma et al., 2019) and optical remote sensing includes multispectral (Kolokoussis \& Karathanassi, 2018), hyperspectral (Lu et al., 2014), thermal infrared (Fingas \& Brown, 1997) to multi-angular (Chust \& Sagarminaga, 2007) and combination between SAR and optical (Setiani \& Ramdani, 2019).

In particular, SAR image systems are useful to detect oil spills due to reducing the electromagnetic backscattering signal relative to the surrounding area resulting in a darker zone in the SAR image (Chaturvedi, Banerjee, \& Lele, 2019). However, there are dark appearances in the SAR image called "oil spill-look alike" results from upwelling phenomena, low winds, natural surface phenomenon induced by plankton or fish, etc. (Alpers, Holt, \& Zeng, 2017; Misra \& Balaji, 2017; Salberg, Rudjord, \& Solberg, 2014). In the SAR images, oil spill and oil spill look-alike cannot be determined unambiguously. To discriminate oil spill look-alike, there are several methods. One of the suitable approaches is to use a combination of multi-sensor satellites (SAR and optical images) (Garcia-Pineda et al., 2020; Setiani \& Ramdani, 2019).

Oil spills determination using remote sensing satellites can be done by several approaches; fully automated, semi-automated, and manual approaches. Automated processing approach starting from the adaptive threshold (Sulma et al., 2019) and supervised classification (Ozigis et al., 2020). The adaptive threshold is applied in the SAR images, while the supervised classification can apply to both SAR and optics. Manual or visual interpretation manually is the most commonly used and carried out by the user to detect oil spills. Although the manual approach can detect different slicks, it is still time-consuming and makes different confidence level depends on the experience of the user (Indregard et al., 2004; Topouzelis, 2008). Even though it is more cost-effective in monitoring large scale than the manual approach, the automated and semi-automated approaches are complex. They require many training data sets for the classifier. The classifier in the optical satellite requires information about band combination, which has spectral response sensitivity to oil spill object in the ocean (Andreou \& Karathanassi, 2011; Dessì et al. 2005; Fingas \& Brown, 2015; Sudibjo et al., 2013). Therefore, this study aims to determine the spectral reflectance of Sentinel-2 response to detecting oil spill on the sea. 
This research was conducted in the Karawang sea area, West Java. It was located about 13 $\mathrm{km}$ towards northeast Pasir Putih Beach. Oil spills from the leakage YYA-1 well belonged to PHE ONWJ polluted Karawang sea and occurred from July 12 until September 21, 2019. The oil platform well was successfully connected with relief wells. The study area showed in Figure 1. The determination of the sampling location was based on a stratified sampling method. There were four locations, one location for clear water and three locations for very slick oil, slick oil, and heavy oil.

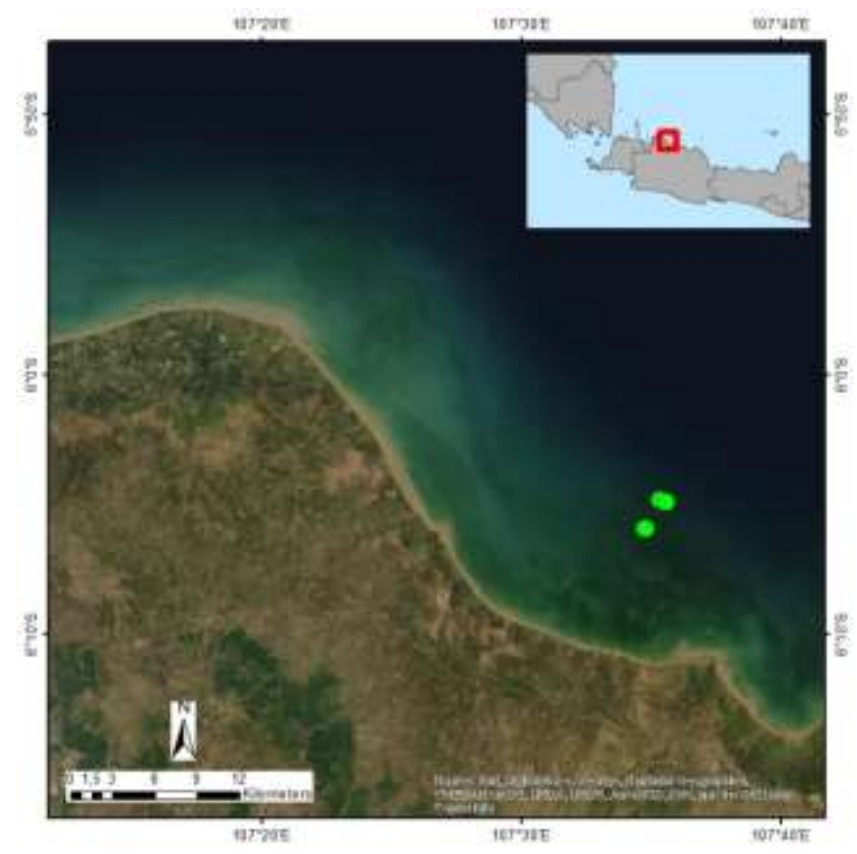

Figure 1. The study area at Karawang waters (Green dots: sampling locations)

\section{Research Methodology}

This research used satellite data and in-situ data to obtain oil spill visualization and the reflectance for each band. Sentinel-2 was used as satellite data because Sentinel-2 imagery provided more consistent results to detect oil spills using OBIA methods with a high degree of capability (Kolokoussis \& Karathanassi, 2018). Another advantage of Sentinel-2 is it provides spatial resolution at $10 \mathrm{~m}$. It is relatively high compared to other medium-resolution satellite imagery, such as Landsat- 8 at $30 \mathrm{~m}$. As Sentinel-2 is a multispectral satellite, it has 13 bands with different wavelengths in each band. Table 1 presents the wavelengths for each band of Sentinel2. As supporting data and information, in-situ data were collected from Visible Near Infrared (VNIR) Handheld Spectroradiometer.

The method's flow chart of this research is shown in Figure 2. It contains two data resources and two outputs. Two resources are satellite data and in-situ observation data, and the two outputs are sentinel- 2 band combination visualization and oil spill spectral reflectance graphic. Graphic of spectral reflectance was obtained from satellite data from Sentinel-2B Level $2 \mathrm{~A}$ orthorectified, which has atmospherically corrected and in-situ data measurement. From Sentinel-2B, the median value of wavelength, and the result was spectral reflectance on all wavelengths, was calculated. In situ data from the VNIR HandHeld spectroradiometer overlayed with spectral reflectance from the satellite. The result was the graphic generation, which helps to 
determine oil reflectance on each band. From this step, it could be to do band combinations and visualization of each band combination.

Table 1. Sentinel-2 bands and wavelengths

\begin{tabular}{|c|c|c|}
\hline Band & Description & Wavelength \\
\hline B1 & Coastal Aerosol & 443,9 nm (S2A) / 442,3 nm (S2B) \\
\hline B2 & Blue & $496,6 \mathrm{~nm}(\mathrm{~S} 2 \mathrm{~A}) / 492,1 \mathrm{~nm}(\mathrm{~S} 2 \mathrm{~B})$ \\
\hline B3 & Green & $560 \mathrm{~nm}(\mathrm{~S} 2 \mathrm{~A}) / 559 \mathrm{~nm}(\mathrm{~S} 2 \mathrm{~B})$ \\
\hline B4 & Red & $664,5 \mathrm{~nm}(\mathrm{~S} 2 \mathrm{~A}) / 665 \mathrm{~nm}(\mathrm{~S} 2 \mathrm{~B})$ \\
\hline B5 & Vegetation Red Edge 1 & $703,9 \mathrm{~nm}(\mathrm{~S} 2 \mathrm{~A}) / 703,8 \mathrm{~nm}(\mathrm{~S} 2 \mathrm{~B})$ \\
\hline B6 & Vegetation Red Edge 2 & $740,2 \mathrm{~nm}(\mathrm{~S} 2 \mathrm{~A}) / 739,1 \mathrm{~nm}(\mathrm{~S} 2 \mathrm{~B})$ \\
\hline B7 & Vegetation Red Edge 3 & $782,5 \mathrm{~nm}(\mathrm{~S} 2 \mathrm{~A}) / 779,7 \mathrm{~nm}(\mathrm{~S} 2 \mathrm{~B})$ \\
\hline B8 & NIR & $835,1 \mathrm{~nm}(\mathrm{~S} 2 \mathrm{~A}) / 833 \mathrm{~nm}(\mathrm{~S} 2 \mathrm{~B})$ \\
\hline B8A & Narrow NIR & $864,8 \mathrm{~nm}(\mathrm{~S} 2 \mathrm{~A}) / 864 \mathrm{~nm}(\mathrm{~S} 2 \mathrm{~B})$ \\
\hline B9 & Water Vapour & $945 \mathrm{~nm}(\mathrm{~S} 2 \mathrm{~A}) / 943,2 \mathrm{~nm}(\mathrm{~S} 2 \mathrm{~B})$ \\
\hline B10 & SWIR-Cirrus & $1373,5 \mathrm{~nm}(\mathrm{~S} 2 \mathrm{~A}) / 1376,9 \mathrm{~nm}(\mathrm{~S} 2 \mathrm{~B})$ \\
\hline B11 & SWIR & $1613,7 \mathrm{~nm}(\mathrm{~S} 2 \mathrm{~A}) / 1610,4 \mathrm{~nm}(\mathrm{~S} 2 \mathrm{~B})$ \\
\hline $\mathrm{B} 12$ & SWIR & $2202,4 \mathrm{~nm}(\mathrm{~S} 2 \mathrm{~A}) / 2185,7 \mathrm{~nm}(\mathrm{~S} 2 \mathrm{~B})$ \\
\hline
\end{tabular}

Source: Google Earth Engine, 2018

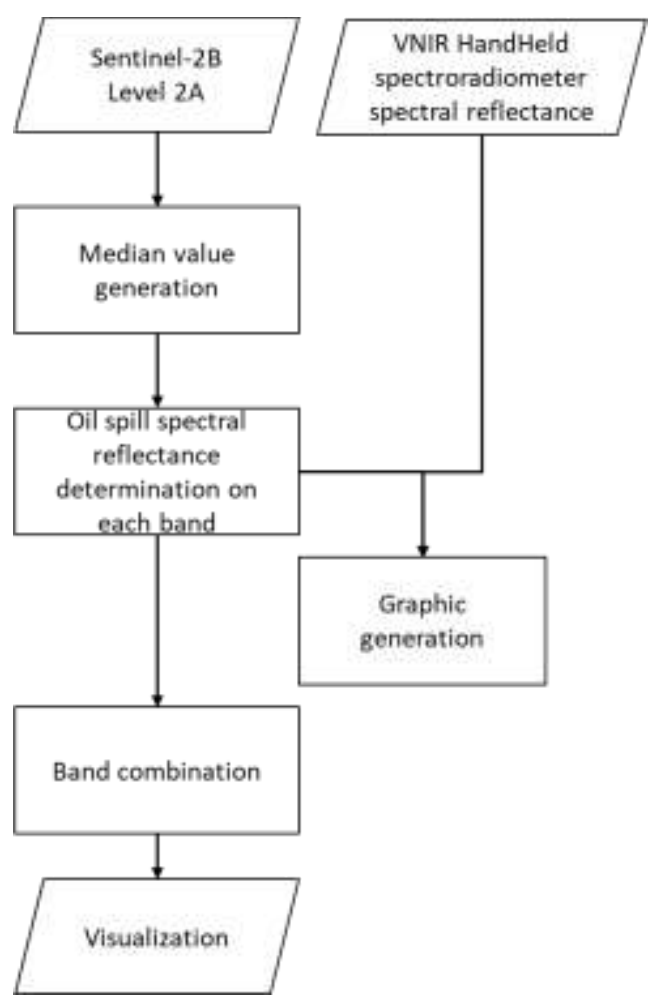

Figure 2. Research flow chart

\subsubsection{Image setup}

Sentinel-2 data were obtained and analyzed using Google Earth Engine (GEE) platform. This cloud platform provides a variety of satellite imagery in raw data and corrected images, either radiometric and atmospheric correction. Furthermore, GEE can be used for processing and visualization. The user only needs to focus on scientific issues, significantly freeing them from programming concerns (Gorelick et al., 2017). 
Sentinel-2B imagery used, which was acquired on August 28, 2019, had atmospheric corrected. GEE allows users to combine the data provided with additional data from outside the platform, to be processed together. In this study, in-situ data were uploaded on GEE's asset to compare the reflectance response with Sentinel-2 reflectance. GEE scripts used the median formula to get the median value of all pixels that fit the criteria. The results are clips according to the area of interest and divided up to get values between 0 and 1 . The reflectance value is obtained based on the location of the in-situ data collection.

\subsubsection{In situ sampling and data analysis}

In-situ data were obtained using ASD Handheld Spectroradiometer. ASD handheld is a handheld spectroradiometer that utilizes the ASD FieldSpec 4 VNIR spectrometer for accurate analysis in the 325 - $1075 \mathrm{~nm}$ spectral range (Prolab, 2020). Data retrieval is undertaken simultaneously with the Sentinel-2B image acquisition time on August 28, 2019, 10:28 local time (Western Indonesia Time). It was intended to have a comparison between spectral reference data of satellite and in situ samplings in the real-time. Also, in situ data are used to validate the spectral reflectance of oil spills captured by satellite. The device records spectral information data on oil, thin oil, and water object.

The analysis in this study used visual interpretation. First, a combination of Red - Green Blue band (natural color) was used to detect the oil layer. Determination of the spectral response of the Sentinel-2 band and in situ data were carried out to find the band or band combination that was most suitable for detecting oil spills. Last, each result was obtained and compared to each other.

\section{Results and Discussion}

In this study, the optical satellite used to detect oil spills is Sentinel-2. Sentinel-2 has 12 bands, which is covered from 443 to $2190 \mathrm{~nm}$. The oil spill was detected visually by a combination of visible bands (Red-Green-Blue). The oil will appear like a silvery sheen that indicates oil coating (Fingas \& Brown, 2015). In this study, the silvery sheen is seen from the oil platform (green dot) and leads to the coastal of Karawang (Figure 3). However, a visible sensor has several lacks to detect the oil. The presence of wind and sun-glint gives the impression of oil appearance in the sea because it will produce silvery sheen too. Moreover, seaweed and black coastlines give the impression of oil appearance (Jha et al., 2008).

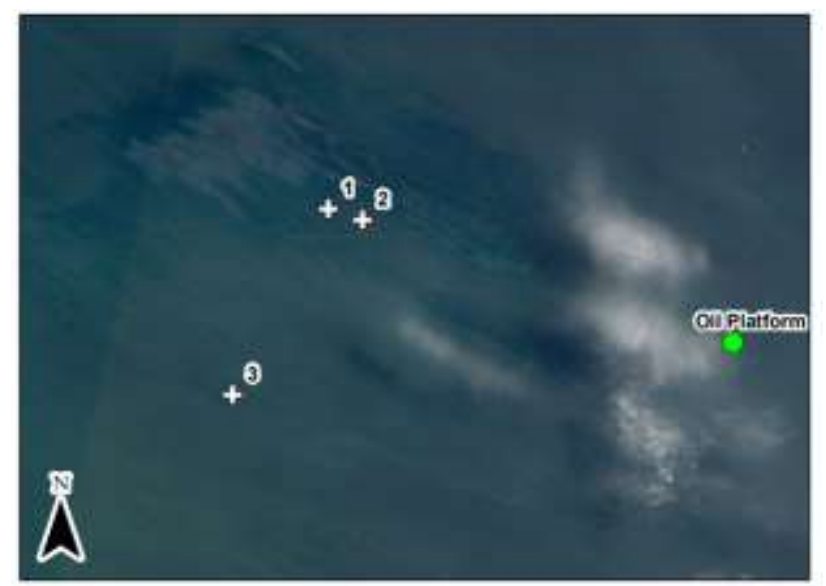

Figure 3. Visualization of oil layer using visible bands Red-Green-Blue 
The determination of the spectral response of the Sentinel-2 band was carried out to find the band or band combination that was most suitable for detecting oil spills (Figure 4). The appearance of the oil spill has a higher reflectivity than the body of water in the visible area, but it shows the same pattern. The difference pattern occurs in band 11, which is Short Wave Infrared (SWIR). It indicates that SWIR is sensitive to oil presence, causing a significant difference in reflectance value.

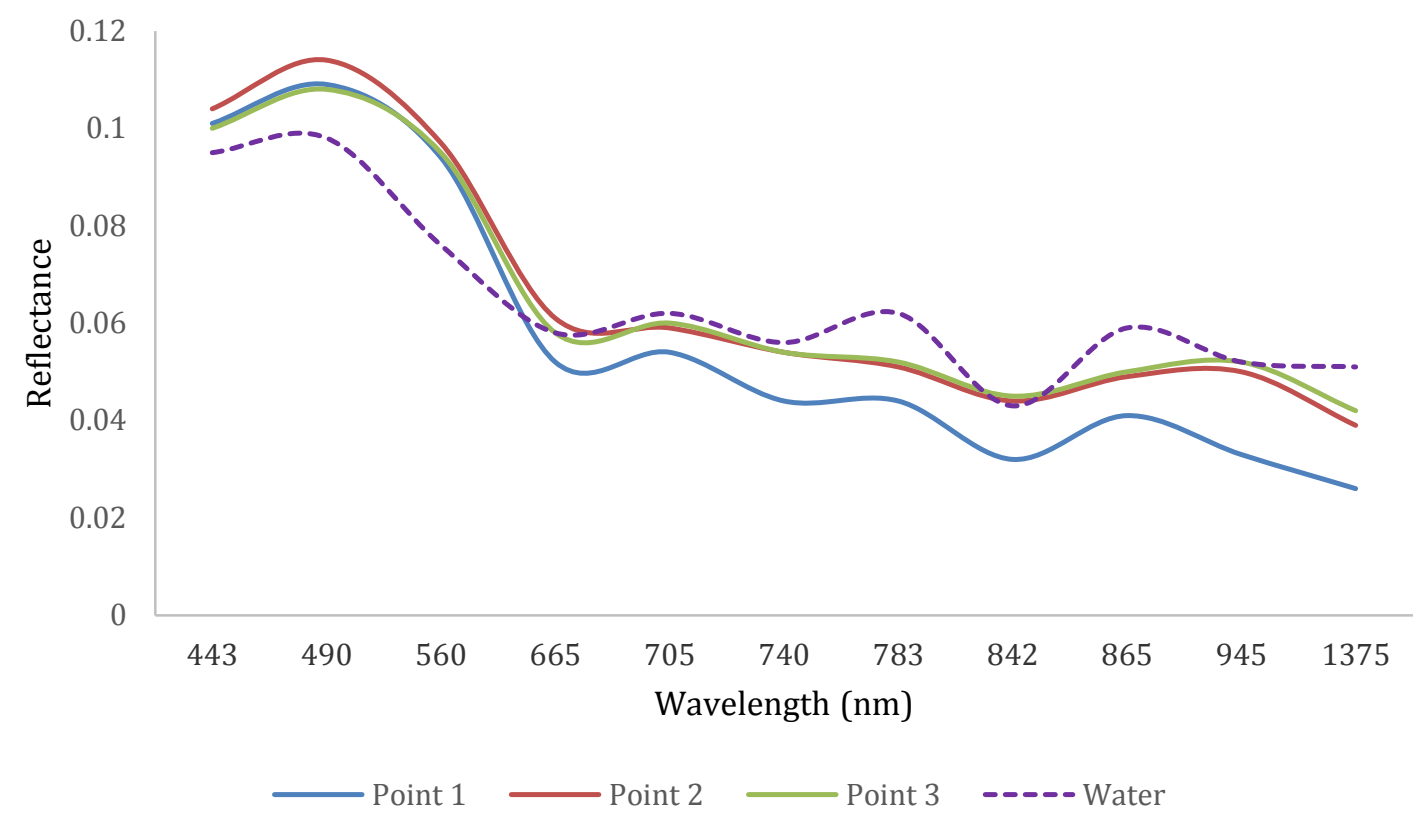

Figure 4. Oil and water spectral reflectance curves across all Sentinel-2 wavelengths

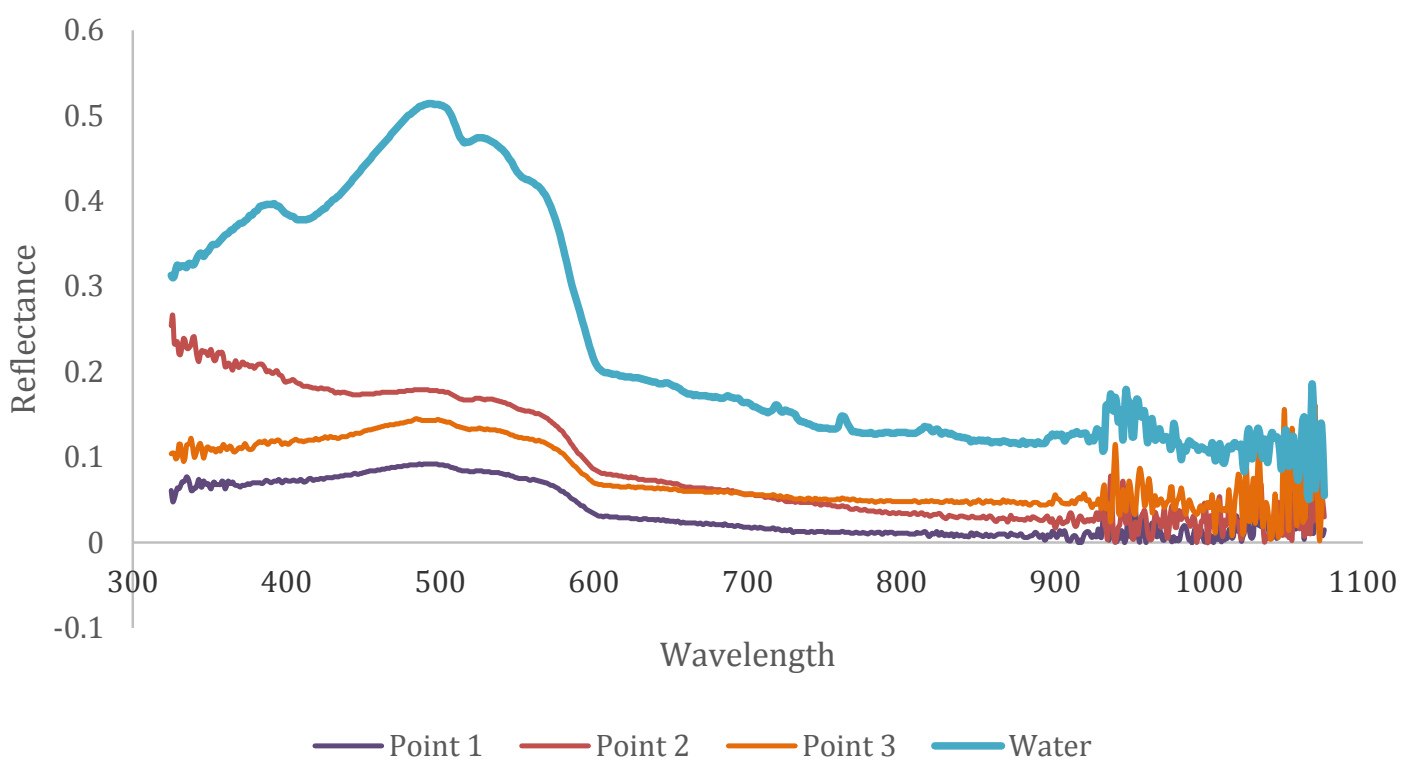

Figure 5. Oil and water spectral reflectance curves across all VNIR handheld spectroradiometer wavelengths 
Measurement of the reflectance value of oil spills in the field was carried out to determine the actual reflection value. Figure 5 presents the results of actual reflectance measurements. Unlike Sentinel-2, actual measurement shows that oil has lower reflectance than water in the visible region and another region.

The results of this study indicate that oil spills in the ocean have lower reflectance than water bodies. It is consistent with other studies (Alawadi, 2011; Andreou \& Karathanassi, 2011). All three sample points of oil spills in the field have high reflectance values at wavelengths of 500 $\mathrm{nm}$ and decrease dramatically at wavelengths of $600 \mathrm{~nm}$. A similar phenomenon also occurs in Sentinel-2 images, which have high reflectance on the blue band (458 - $523 \mathrm{~nm}$ ) and decrease dramatically on the Red band (650 - $680 \mathrm{~nm}$ ). Dessì et al. (2005) also found that in the blue band, an oil layer has the highest reflectance than water.

The absorption of infrared radiation by constituent molecules of the material causes its single bonds to vibrate. This vibration causes the absorption band to rise according to the combination of the chemical functional groups. The principle of NIR spectroscopic theory is an unharmonious movement of chemical bonds that causes molecular vibrations with low electronic absorption transition energies (Karlinasari et al., 2012). The main compounds that makeup petroleum are hydrocarbons. The hydrocarbons in petroleum are mainly alkanes, and the rest are alkenes, alkyne, and aromatic compounds (Tissot \& Welte, 1978). These hydrocarbons have bonds between carbons $(\mathrm{C}=\mathrm{C})$ and bonds between carbon and hydrogen $(\mathrm{C}$ $\mathrm{H}$ ), which vibrate when they absorb infrared waves (National Research Council, 1985). When detected by Near Infrared (NIR) band, it appears that the oil reflects less light, so the reflectance value is low. Liu et al. (2016) experimented with measuring the reflectance data of water and oil films at the $0,1 \mathrm{st}, 3 \mathrm{rd}, 12 \mathrm{th}$, and 48th hours of weathered oil films. The results showed that after 48 hours, the potential sensitive bands were distributed mainly in the near-infrared region. The reflectance of oil films at the 0,1 st, and 3rd hours of weathering are all higher than that of water at the visible and NIR bands with distinct reflection characteristics. Andreou \& Karathanassi (2011) explain that this occurs because the oil on the sea surface is influenced by sea-level waves. The same thing occurs when using the band SWIR. Satellite image analysis confirms that only thick patches are highlighted by the SWIR wavelengths. For environmental protection, SWIR images will help target interventions where oil is thicker (Dubucq et al., 2016). Figure 6 shows the visualization of oil in Red, NIR, and SWIR.

Thus, the SWIR-NIR-RED combination was chosen in this study to detect oil spills using Sentinel-2. Different from the combination of visible bands, the combination of SWIR-NIR-Red bands produce a silvery sheen with the surrounding black color (Figure 7).

According to (Jha et al., 2008), the silvery sheen oil spill in the combination of SWIR- NIR Red bands has a thickness of about $0,05 \mu \mathrm{m}$. Meanwhile, the dark oil spill approximately $10 \mu \mathrm{m}$. The darker an oil spill, the higher its thickness layer. The thickness of the oil affects its reflectance. If it is thicker, then the reflectance will be lower due to more energy that is absorbed. Conditions in the field support it. Point 1 is an area that has a lot of thick oil and has undergone treatment. This condition causes Point 1 to have the lowest reflectance value compared to other locations with thinner oil (Figure 8). 


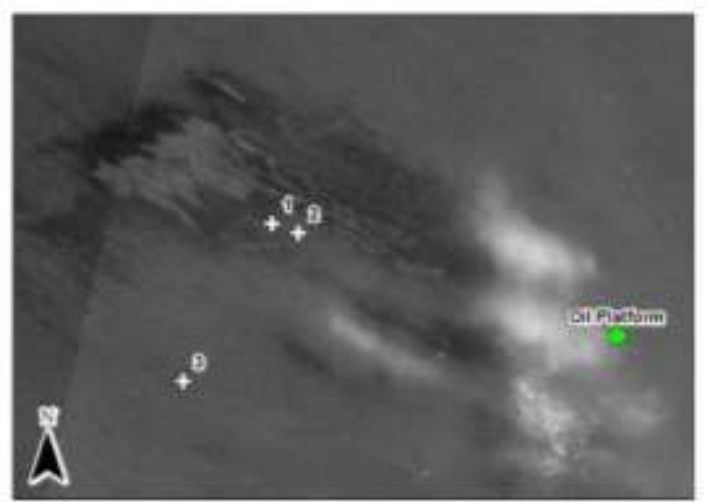

(A) AED: 160000

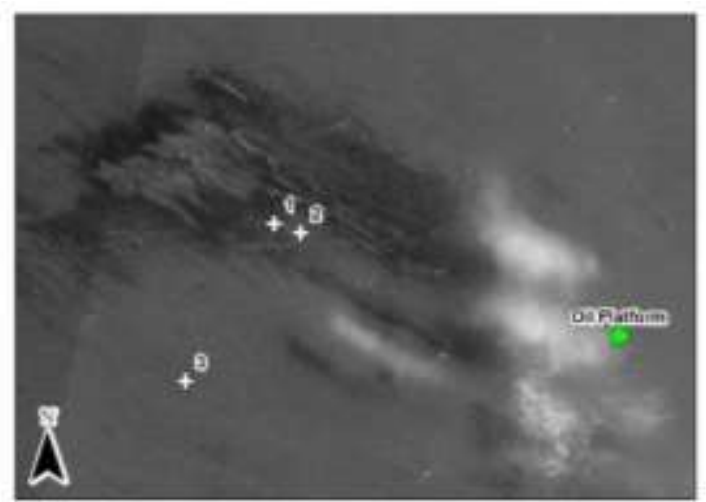

(B) NIR 150.000

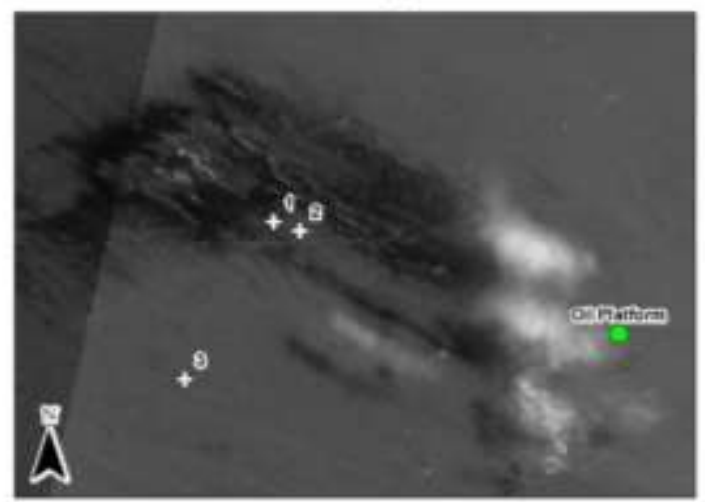

(C) SWRe 150000

Figure 6. Visualization of oil layer using a) Red band; b) NIR band; c) SWIR band

(A) RED-GREEN-BLUE: $1 \cdot 50,000$

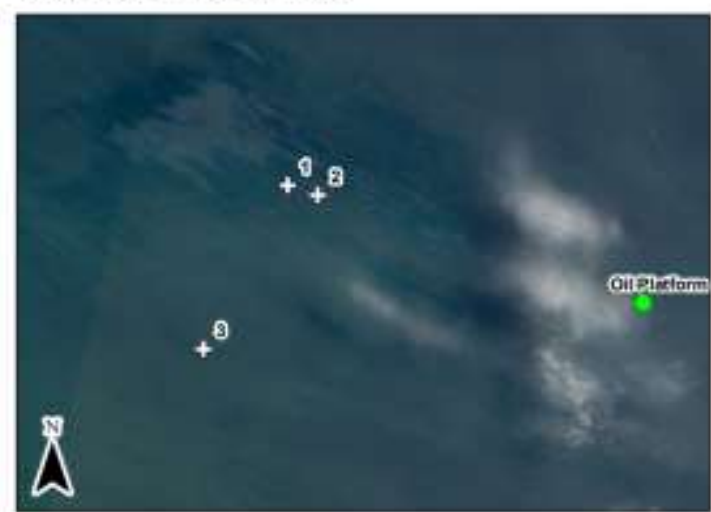

(B) SWIR-NIR-RED; 1:50,000

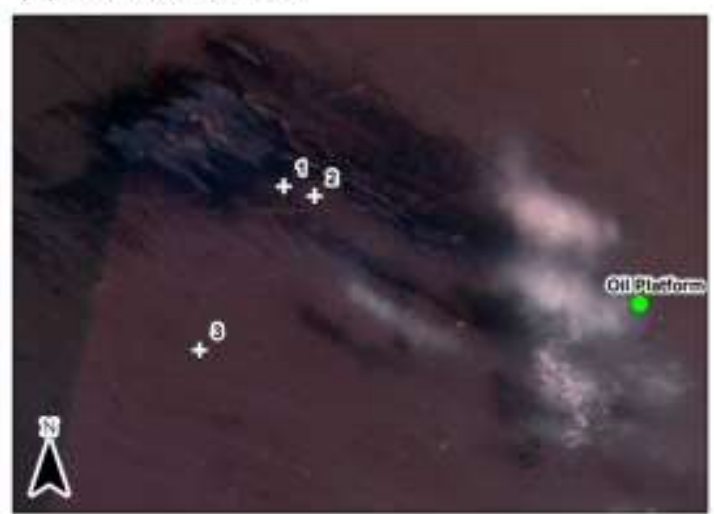

Figure 7. Visualization of oil layer using band combination a) Red-Green-Blue; b) SWIR-NIR-Red 


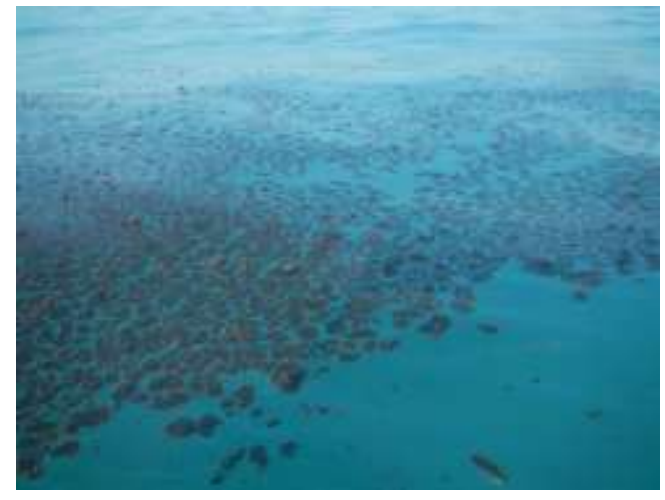

a) Point 1. Thick oil layer, and it has been skimmed.

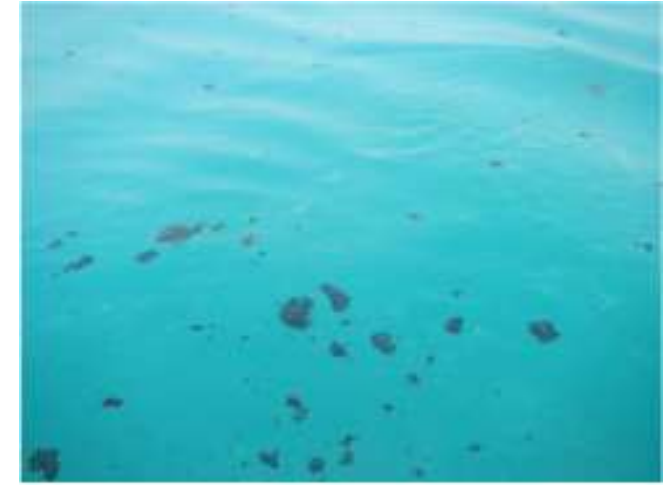

b) Point 2. Thin oil layer.

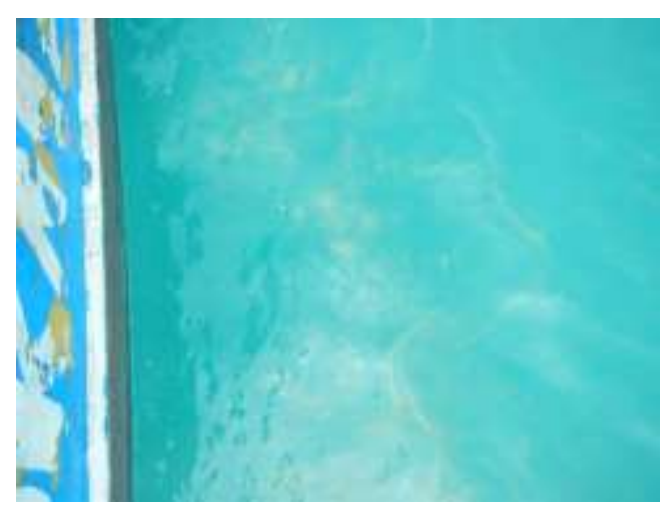

c) Point 3. Thin and slightly oil layer

Figure 8. In situ water conditions

\section{Conclusion}

Spectral reflectance has been analyzed to find bands sensitive to oil spill detection, both from in situ and satellite data. Based on in situ and satellite data, the reflectance at the NIR and SWIR bands between the oil spill and water is significantly different, making the two bands important in the oil spill case. Preliminary results are considered successful in determining the spectral band of Sentinel-2, which is suitable for the detection of oil spills. Based on the visual interpretation method, the most appropriate band combination for determining oil spills on the sea surface is the SWIR-NIR-Red combination. Further testing to determine the spectral reflectance based on the characteristics and type of oil on the sea surface needs to be carried out.

\section{Acknowledgment}

The author would like to thanks the Remote Sensing Application Center, LAPAN, which supports funding for this research. We thank the field survey team and PHE ONWJ, which support the field survey, and thanks to anonymous reviewers. All authors have the same contribution divided by Pingkan Mayestika Afgatiani (analysis, data processing, and writing), Fanny Aditya Putri (analysis, data processing, and writing), Argo Galih Suhadha (data processing and writing), and Andi Ibrahim (data display, writing, and editing). 


\section{References}

Alawadi, F. A. M. (2011). Detection and Classification of Oil Spills in MODIS Satellite Imagery. University of Southampton. University of Southampton.

Albert, O. N., Amaratunga, D., \& Haigh, R. P. (2018). Evaluation of the Impacts of Oil Spill Disaster on Communities and Its Influence on Restiveness in Niger Delta, Nigeria. In Procedia Engineering (Vol. 212, pp. 1054-1061). Elsevier B.V. http://doi.org/10.1016/j.proeng.2018.01.136

Alpers, W., Holt, B., \& Zeng, K. (2017). Oil spill detection by imaging radars: Challenges and pitfalls. Remote Sensing of Environment, 201(August), 133-147. http://doi.org/10.1016/j.rse.2017.09.002

Andreou, C., \& Karathanassi, V. (2011). Endmember detection in marine environment with oil spill event. In Image and Signal Processing for Remote Sensing XVII (Vol. 8180, p. 81800P). http://doi.org/10.1117/12.898762

Chaturvedi, S. K., Banerjee, S., \& Lele, S. (2019). An assessment of oil spill detection using Sentinel 1 SAR-C images. Journal of Ocean Engineering and Science. http://doi.org/10.1016/j.joes.2019.09.004

Chust, G., \& Sagarminaga, Y. (2007). The multi-angle view of MISR detects oil slicks under sun glitter conditions. Remote Sensing of Environment, 107(1-2), 232-239. http://doi.org/10.1016/j.rse.2006.09.024

Dessì, F., Melis, M. T., Naitza, L., \& Marini, A. (2008). MODIS data processing for coastal and marine environment monitoring: A study on anomaly detection and evolution in gulf of Cagliari (SardiniaItaly). In The International Archives of the Photogrammetry, Remote Sensing and Spatial Information Sciences, ISPRS Congress Beijing 2008, Proceedings of Commission VIII (pp. 695-698). Beijing, China: ISPRS.

Elum, Z. A., Mopipi, K., \& Henri-Ukoha, A. (2016). Oil exploitation and its socioeconomic effects on the Niger Delta region of Nigeria. Environmental Science and Pollution Research, 23(13), 12880-12889. http://doi.org/10.1007/s11356-016-6864-1

Fan, K., Zhang, Y., \& Lin, H. (2010). Satellite SAR analysis and interpretation of oil spill in the offshore water of Hong Kong. Annals of GIS, 16(4), 269-275. http://doi.org/10.1080/19475683.2010.540259

Fingas, M., \& Brown, C. (2014). Review of oil spill remote sensing. Marine Pollution Bulletin, 83(1), 9-23. http://doi.org/10.1016/j.marpolbul.2014.03.059

Fingas, M. F., \& Brown, C. E. (1997). Review of oil spill remote sensing. Spill Science and Technology Bulletin, 4(4), 199-208. http://doi.org/10.1016/S1353-2561(98)00023-1

Garcia-Pineda, O., Staples, G., Jones, C. E., Hu, C., Holt, B., Kourafalou, V., ... Haces-Garcia, F. (2020). Classification of oil spill by thicknesses using multiple remote sensors. Remote Sensing of Environment, 236(August 2019), 111421. http://doi.org/10.1016/j.rse.2019.111421

Gorelick, N., Hancher, M., Dixon, M., Ilyushchenko, S., Thau, D., \& Moore, R. (2017). Google Earth Engine: Planetary-scale geospatial analysis for everyone. Remote Sensing of Environment, 202, 18-27. http://doi.org/10.1016/j.rse.2017.06.031

Iqbal, D. (2019). Rugi Segala Lini Akibat Tumpahan Minyak Pertamina. Retrieved from https://www.mongabay.co.id/2019/09/18/rugi-segala-lini-akibat-tumpahan-minyak-pertamina/

Jha, M. N., Levy, J., \& Gao, Y. (2008). Advances in remote sensing for oil spill disaster management: State-ofthe-art sensors technology for oil spill surveillance. Sensors, 8(1), 236-255. http://doi.org/10.3390/s8010236

Karlinasari, L., Sabed, M., Wistara, N. J., Purwanto, A., \& Wijayanto, H. (2012). Karakteristik Spektra Absorbansi NIR (Near Infra Red) Spektroskopi Kayu Acacia mangium WILLD pada 3 Umur Berbeda. Jurnal Ilmu Kehutanan, 6(1), 45-52. http://doi.org/10.22146/jik.3310

Kolokoussis, P., \& Karathanassi, V. (2018). Oil spill detection and mapping using sentinel 2 imagery. Journal of Marine Science and Engineering, 6(1), 4. http://doi.org/10.3390/jmse6010004

Lamrotua Sihombing, V., Nurweda Putra, I. D. N., \& Arya Sasmita, G. M. (2018). Aplikasi Deteksi Tumpahan Minyak dengan Interpretasi Citra Satelit Landsat 8. Jurnal Ilmiah Merpati (Menara Penelitian Akademika Teknologi Informasi), 6(3), 244. http://doi.org/10.24843/jim.2018.v06.i03.p11

Liu, B., Li, Y., Zhang, Q., \& Han, L. (2016). Spectral Characteristics of Weathered Oil Films on Water Surface and Selection of Potential Sensitive Bands in Hyper-Spectral Images. Journal of the Indian Society of 
Remote Sensing, 45(1), 171-177. http://doi.org/10.1007/s12524-016-0568-3

Lu, Y. C., Fu, W. X., Tian, Q. J., Lyu, C. G., \& Han, W. C. (2014). Using optical remote sensing model to estimate oil slick thickness based on satellite image. IOP Conference Series: Earth and Environmental Science, 17(1), 12122. http://doi.org/10.1088/1755-1315/17/1/012122

Misra, A., \& Balaji, R. (2017). Simple Approaches to Oil Spill Detection Using Sentinel Application Platform (SNAP)-Ocean Application Tools and Texture Analysis: A Comparative Study. Journal of the Indian Society of Remote Sensing, 45(6), 1065-1075. http://doi.org/10.1007/s12524-016-0658-2

Ozigis, M. S., Kaduk, J. D., Jarvis, C. H., da Conceição Bispo, P., \& Balzter, H. (2020). Detection of oil pollution impacts on vegetation using multifrequency SAR, multispectral images with fuzzy forest and random forest methods. Environmental Pollution, 256, 1-17. http://doi.org/10.1016/j.envpol.2019.113360

Prolab. (2020). ASD HandHeld 2: Hand-held VNIR Spectroradiometer.

Salberg, A. B., Rudjord, O., \& Solberg, A. H. S. (2014). Oil spill detection in SAR images - A review. IEEE Transactions Oh Geoscience and Remote Sensing, 52(10), 0196-2892.

Setiani, P., \& Ramdani, F. (2019). Oil spill mapping using multi-sensor Sentinel data in Balikpapan Bay, Indonesia. In 2018 4th International Symposium on Geoinformatics, ISyG 2018 (pp. 1-4). IEEE. http://doi.org/10.1109/ISYG.2018.8612057

Spies, R. B., Mukhtasor, M., \& Burns, K. A. (2017). The Montara Oil Spill: A 2009 Well Blowout in the Timor Sea. Archives of Environmental Contamination and Toxicology, 73(1), 55-62. http://doi.org/10.1007/s00244-016-0356-7

Sudibjo, M., Siregar, V. P., \& Gaol, J. L. (2013). Algoritma Untuk Deteksi Tumpahan Minyak Di Laut Timor Menggunakan Citra Modis. Jurnal Teknologi Perikanan Dan Kelautan, 4(1), 41-62.

Sulistyono. (2013). Dampak Tumpahan Minyak (Oil Spill) di Perairan Laut Pada Kegiatan Industri Migas dan Metode Penanggulangannya. Forum Teknologi, 3(1), 49-57.

Sulma, S., Insan, K., Rahmi, N., Febrianti, N., \& Sitorus, J. (2019). Deteksi Tumpahan Minyak Menggunakan Metode Adaptive Threshold dan Analisis Tekstur pada Data SAR. Majalah Ilmiah Globe, 21(1), 45-52.

Tissot, B. P. \& D. H. W. (1978). Petroleum Formation and Occurrence: A New Approach to Oil and Gas Exploration. New York: Springer-Verlag. http://doi.org/10.1017/S0016756800043685

Yolanda, F. (2019). Kerugian Petani Garam Akibat Tumpahan Minyak Rp 700 Juta. 